\title{
Use of an Agar-gel Technique for Large Scale Application to Recover Ascaris suum Larvae from Intestinal Contents of Pigs
}

\author{
By H.-C. Slotved. E. H. Barnes, L. Eriksen, A. Roepstorff, P. Nansen and H. Bjørn \\ Danish Centre for Experimental Parasitology, The Royal Veterinary and Agricultural University, Frederiksberg, \\ Denmark.
}

\begin{abstract}
Slotved, H.-C., E.H. Barnes, L. Eriksen, A. Roepstorff, P. Nansen and H. Bjørn: Use of an agar-gel technique for large scale application to recover Ascaris suum larvae from intestinal contents of pigs. Acta vet. scand. 1997, 38, 207-212. - Four groups each of 3 pigs were inoculated with Ascaris suum eggs. Pigs in groups 1 and 3 were inoculated with 1000 eggs, and pigs in groups 2 and 4 with 10000 eggs. On day 10 and 21 post-inoculation (p.i.), respectively, groups $1+2$ and $3+4$ were slaughtered, and the contents from the small intestines collected. The contents were mixed with agar to a final concentration of $1 \%$ agar and allowed to sediment. The larvae were allowed to migrate from the agar-gel into $38^{\circ} \mathrm{C} 0.9 \%$ saline overnight, and were then collected on a sieve ( $20 \mu \mathrm{m}$ mesh) and counted. The larvae retained in the agar-gel were counted after pouring the melted agar through a sieve $(20 \mu \mathrm{m}$ mesh). The results showed that more than $97 \%$ of the larvae migrated out of the agar-gel and were available for counting in an almost clean suspension. The inoculation dose level did not significantly affect the recovery percentage, neither did the larval stage ( 10 or 21 days old larvae). The variation in the time interval from slaughtering to start of incubation (interval 57-155 min) did not significantly affect the recovery percentage.
\end{abstract}

worm; recovery; migration; nematodea.

\section{Introduction}

The most commonly used method for counting intestinal nematodes in animals is the manual collection of individual worms from the intestinal contents (Arundel 1967). This method is time-consuming and hampered by difficulties in discriminating small nematodes from debris of the intestinal contents.

Jørgensen (1975) and Mwegoha \& Jørgensen (1977) isolated nematode larvae from grass samples by embedding sediments from washings in agar-gel. Van Wyk \& Gerber (1978) modified this agar-gel technique to obtain nematodes from the gastrointestinal contents of sheep. Later, this technique was tested on a larger scale and recoveries of more than $90 \%$ of nematodes from the intestines of both calves and sheep were achieved (Van Wyk et al. 1980). In our laboratory, this agar-gel procedure was successfully used to recover Oesophagostomum dentatum from large intestinal contents of pigs (Bjørn et al. 1995), and the efficiency of this technique has recently been shown to be $>95 \%$ for both immature and adult nodular worms (Slotved et al. 1996).

The objective of the present study was to optimize and standardize the agar-gel technique for routine isolation and enumeration of Ascaris suum larvae from the small intestinal contents of pigs. 


\section{Materials and methods}

This methodological experiment was carried out as part of a larger study on $A$. suum single infection (Roepstorff et al. in press).

\section{Experimental animals}

Twelve crossbred Danish Landrace $\times$ Yorkshire $\times$ Duroc pigs, weighing approximately $20 \mathrm{~kg}$, were obtained from an experimental farm (Sjælland III). The pigs had free access to water and were fed a standard ration of ground barley and protein supplement throughout the study. Prior to the start of the experiment, the parasite free status of the pigs was confirmed by faecal examinations using a modified McMaster technique (at week -2 and 0 ), and an indirect ELISA on bloodsamples (at week 0 ).

\section{Parasite}

The employed strain of A. suum (Batch no. Asc1) was isolated in 1993 and since then maintained at our laboratory by passage in helminth naive pigs. The eggs were embryonated as described by Oksanen et al. (1990). Briefly, the eggs were isolated from faeces and embryonated in $0.1 \mathrm{~N} \mathrm{H}_{2} \mathrm{SO}_{4}$ for at least 3 months at room temperature.

\section{Experimental design}

Twelve pigs were divided into 4 groups each of 3 pigs. On day 0 pigs of groups 1 and 3 were inoculated with $1000 \mathrm{~A}$. suum eggs and pigs of groups 2 and 4 with 10000 eggs. The inoculation of infective eggs was performed via a stomach tube. Groups 1 and 2 were slaughtered on day 10 post infection (p.i.) and groups 3 and 4 on day 21 p.i. This design allowed an evaluation of the technique at both low and high intestinal worm burdens and with 2 different developmental stages of larvae. Larvae older than 21 days have normally grown to a size where they can easily be identified in the intestinal contents by the naked eye, and thus, the use of the agar- gel technique in late infection is of less interest.

\section{Procedure for worm recovery}

The pigs were killed using a captive bolt pistol, bled, eviscerated, and the small intestines were subsequently isolated. The time interval between slaughter of the pigs and start of the incubation of intestinal contents was recorded in order to evaluate whether this affected worm recoveries. From each pig the small intestine was divided into 4 sections of equal length, numbered I-IV from duodenum to ileum. Each section of the small intestine was opened and the contents and the mucus were scraped off, whereafter the gut wall was washed in $38^{\circ} \mathrm{C}$ $0.9 \%$ saline. The contents, mucus and washings from each section were resuspended in $0.9 \%$ saline to obtain a final volume of $500 \mathrm{ml}$. The drymatter content of this was determined by incubation of a representative sample at $100^{\circ} \mathrm{C}$ for $48 \mathrm{~h}$.

\section{Embedment in agar-gel}

The procedure used is described in Slotved et al. (1996). Briefly, the $500 \mathrm{ml}$ sample was mixed with $500 \mathrm{ml}$ of $48^{\circ} \mathrm{C} 2 \%$ agar-solution (Difco, Bacto-Agar) and immediately poured onto 3 trays $(23 \times 32 \times 1.5 \mathrm{~cm})$ of stainless steel with disposable cotton cloths (Johnson \& Johnson, medical cloth, $22 \times 34 \mathrm{~cm}$ ). If the intestinal contents could not be reduced to $500 \mathrm{ml}$, then $650 \mathrm{ml}$ contents $+650 \mathrm{ml}$ agar were mixed and 4 gels were made. After the agar-gels had solidified within few min, they were all placed in a vertical position in a container $(23 \times 34 \times 6 \mathrm{~cm})$ filled with $38^{\circ} \mathrm{C} 0.9 \%$ saline and incubated at $38^{\circ} \mathrm{C}$ overnight.

\section{Recovery of worms}

The following day the larvae which had migrated out of the gels and sedimented on the bottom of the container were collected on a 
sieve (20 $\mu \mathrm{m}$ mesh) and stored in a $50 \mathrm{ml}$ tube in $5 \%-10 \%$ iodine $(80 \mathrm{~g}$ iodine $+400 \mathrm{~g}$ potassium iodide $+800 \mathrm{~g}$ distilled $\mathrm{H}_{2} \mathrm{O}$ ) for subsequent worm counts.

To recover residual larvae remaining in the agar-gels, the agar-gels and the cloths were removed from the containers, mixed with tapwater and melted by heating the mixture to the boiling point. After sieving through a sieve (20 $\mu \mathrm{m}$ mesh) the residue with the worms was collected in addition to all the cloths, preserved with $5 \%-10 \%$ iodine as described above and stored in $500 \mathrm{ml}$ containers at room temperature for subsequent worm counts.

\section{Counting of worms}

All worms from the $50 \mathrm{ml}$ tube (containing the worms which migrated out of the agar-gel) were examined and counted under a stereo microscope. A $25 \%$ subsample from the $500 \mathrm{ml}$ container (containing the residual worms) plus one randomly chosen cloth were examined under a stereo microscope for enumerating possible remaining worms.

\section{Statistical analysis}

The recovery percentage of worms was calculated for each intestinal section and pig. This was done by dividing the number of worms that migrated out of the agar-gel by the total number of worms, i.e. the number of worms that had left the gel plus the number of worms retained in the gel, and then converting this into a percentage. The proportions of worms recovered from the entire small intestine by the agar-gel method were arcsine-transformed (Daniel 1991) and subjected to analysis of variance to test for the effect of day of slaughter, inoculation dose and their interaction, mean percent dryweight of the total intestinal contents and the time lapse between slaughtering and start of the incubation. All statistical analyses were performed using SAS Release 6.04 (SAS Institute Inc. 1990).

\section{Results}

The worms recovered by the agar-gel technique were obtained in an almost clean suspension, which allowed a counting time approximately 3-6 times faster than required by the traditional manual method.

As soon as the agar-gel was placed in the container at $38^{\circ} \mathrm{C}$, it was observed that the worms immediately began to migrate out, and it was the impression that most worms had left the agar-gel within $3 \mathrm{~h}$.

Table 1 shows the numbers of larvae and the recovery percentages by the agar-gel method for each intestinal section and the entire small intestine of each pig. Except for one recovery percentage in group 4, pig 357 section II (89.5\%), recovery from all the sections was higher than $90 \%$. The recovery percentage achieved by the agar-gel method for each section was very high, despite considerable differences in numbers of worms in each section (varied from 1 to 6136 worms) (Table 1). For the entire small intestine the lowest recovery percentage was $92.5 \%$ (group 4 pig 357).

The mean total worm recovery and standard deviation (S.D.) for the small intestine in the pigs in each group are shown in Table 2. The range of group mean worm recovery was $97.5 \%$ to $100 \%$, independent from the wide range of worm counts.

For day 10 , the percentage of the number of larvae inoculated that established in the small intestine ranged from $43 \%$ to $81 \%$ in all pigs (Groups 1 and 2, Table 1). At day 21 a reduction in establishment was observed (range $0.1 \%$ to $3 \%$, Groups 3 and 4, Table 1), as previously observed by Jørgensen et al. (1975). Despite the different worm burdens the agar-gel recovery percentage for each pig was still very high and did not seem to be affected by establishment on either both day (Table 1).

By analysis of variance it was found that the efficacy of the agar-gel technique for recovering 


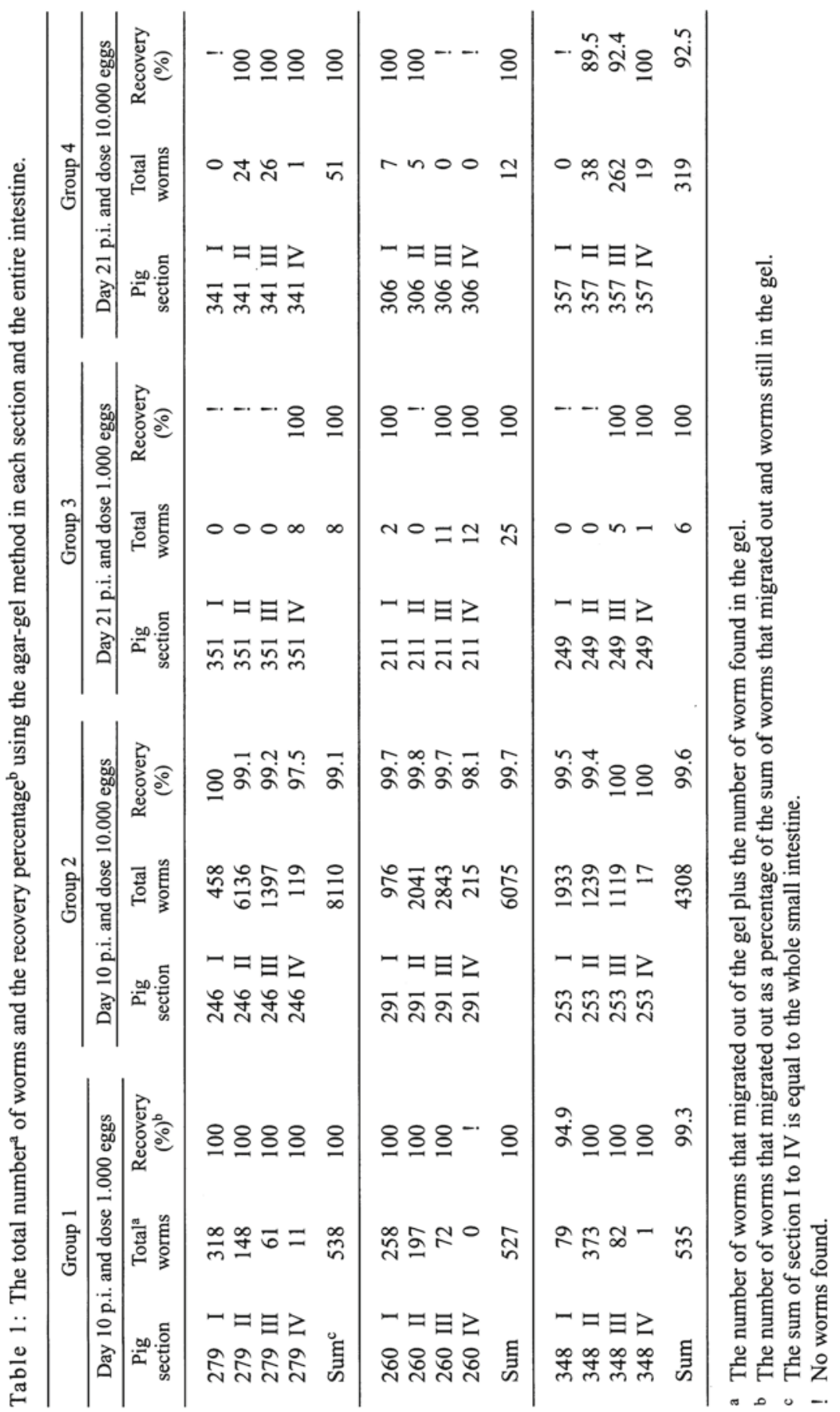


Table 2. Mean number and standard deviation of total number of worms and recovery percentage by the agargel method from each group.

\begin{tabular}{lcccc}
\hline & $\begin{array}{c}\text { Group 1, day 10 p.i. } \\
\text { and dose 1.000 eggs } \\
\text { 3 pigs }\end{array}$ & $\begin{array}{c}\text { Group 2, day 10 p.i. } \\
\text { and dose 10.000 eggs }\end{array}$ & $\begin{array}{c}\text { Group 3, day 21 p.i. } \\
\text { and dose 1.000 eggs }\end{array}$ & $\begin{array}{c}\text { Group 4, day 21 p.i. } \\
\text { and dose 10.000 eggs } \\
\text { 3 pigs }\end{array}$ \\
\hline Worms $^{\text {a }}$ (intestine) & 533 & 6164 & 13 & 127 \\
S.D. & 6 & 1903 & 10 & 167 \\
Recovery \%c (instestine) & 99.8 & 99.5 & 100 & 97.5 \\
S.D. & 0,4 & 0,3 & 0 & 4.3 \\
\hline
\end{tabular}

a The average of the total number of worms (worms recovered + worms in gel) in the 3 intestines in each group.

b Standard deviation.

c Recovery percent $=$ worms recovered $/($ worms recovered + worms in gel) .

worms was not significantly affected by the day of slaughter, infection dose or their interaction, dry weight or the time interval from slaughtering to the start of incubation (interval of $57 \mathrm{~min}$ to $155 \mathrm{~min})$ ( $\mathrm{p}>0.05$ in all cases).

\section{Discussion}

This study has clearly illustrated that the agargel technique may be used as a routine method to recover $A$. suum from the intestinal contents of pigs. The method provides an almost clean worm suspension which reduces the counting time compared to the traditional manual method by a factor of 3-6.

It is noteworthy that the migration of worms from the agar-gel did not seem to be adversely affected by mixing the intestinal contents with $48^{\circ} \mathrm{C}$ warm agar. Neither did a time lapse of 57 min-155 min between slaughter and incubation in agar exert any significant influence. For practical reasons it will be important to examine whether this period may be extended further without affecting the parasites migratory ability in agar.

The agar-gel technique has previously been used to isolate trichostrongyle nematode larvae from herbage (Jørgensen 1975, Mwegoha \& Jørgensen 1977), and strongyle nematodes from gastro-intestinal contents of sheep, cattle and pigs (Van Wyk \& Gerber 1978, Van Wyk et al. 1980, Van Wyk et al. 1984, Bjørn et al. 1995, Slotved et al. 1996). In the present study, it was demonstrated that the method can also be employed to isolate the tiny, immature A. suum larvae from the small intestinal contents of pigs. The mean efficiency of the method ranged from $97.5 \%$ to $100 \%$ (Table 2). These percentages are comparable to or even higher than those obtained by Van Wyk et al. (1980) and Slotved et al. (1996). The varying worm burden in individual pigs did not seem to affect the agar-gel recovery percentage, which ranged from $92.5 \%$ to $100 \%$ for individual pigs (Table 1). The recovery was high in all sections of the small intestine (Table 1).

The method makes it easy to count worms in the intestinal contents. By reducing the time for counting the worms in a given subsample by 3-6 times using the agar-gel technique, it is now possible to carry out large scale experiments within an acceptable time period. The technique furthermore provides clean live parasites which may be used in a range of studies, e.g. those involving transplantation of live worms from one animal to another (Bjørn et al. 1995). 


\section{Acknowledgements}

This study was supported by the Danish National Research Foundation. The skilful technical assistance of technicians and animal attendants is gratefully acknowledged.

\section{Reference}

Arundel JH: Field procedure for counting gastrointestinal worms in sheep and cattle. Aust. vet. J., 1967, 43, 592-593.

Bjørn H, Roepstorff A, Grøndahl C, Eriksen L, Bjerregaard $J$, Nansen $P$ : Experimental transfer of adult Oesophagostomum dentatum from donor to helminth naive recipient pigs. A methodological study. J. Helminth. 1995, 69, 279-283.

Daniel WD: Biostatistics: A foundation for analysis in the health sciences. 5th Edition, Wiley, New York, 1991, 318 pp.

Jørgensen RJ: Isolation of infective Dictyocaulus larvae from herbage. Vet. Parasitol. 1975, 1, 61-67.

Jørgensen RJ, Nansen P, Nielsen K, Eriksen L, Andersen $S$ : Experimental Ascaris suum infection in the pig. Population kinetics following low and high levels of primary infection in piglets. Vet. Parasitol., 1975, 1, 151-157.

Mwegoha $W H$, Jørgensen RJ: Recovery of infective 3rd stage larvae of Haemonchus contortus and Ostertagia ostertagi by migration in agar gel. Acta vet. scand., 1977, 18, 293-299.

Oksanen A, Eriksen L, Roepstorff A, Ilsø B, Nansen P, Lind P: Embryonation and infectivity of Ascaris suum eggs. A comparison of eggs collected from worm uteri with eggs isolated from pig faeces. Acta. vet. scand., 1990, 31, 393-398.

Roepstorff A, Eriksen L, Slotved H-C, Nansen P: Experimental Ascaris suum infection in the pig: Worm populations kinetics following single inoculation with three doses of infective eggs. (in press in Parasitology).

Slotved H-C, Barnes EH, Bjørn H, Christensen CM, Eriksen L, Roepstorff A, Nansen P: Recovery of Oesophagostomum dentatum from pigs by isolation of parasites migrating from large intestinal contents embedded in agar-gel. Vet. Parasitol., 1996, 63, 237-245.
SAS Institute Inc.: SAS/STAT Users Guide, Version 6, 4th Edition, 1990. Cary, NC, USA.

Van Wyk JA, Gerber HM: Recovery of nematodes from ruminants by migration from gastro-intestinal ingesta and mucosa gelled in agar: preliminary report. Onderstepoort J. Vet. Res., 1978, 45, 29-38.

Van Wyk JA, Gerber HM, Groeneveld HT: A technique for the recovery of nematodes from ruminants by migration from gastro-intestinal ingesta gelled in agar: Large-scale application. Onderstepoort J. Vet. Res., 1980, 47, 147-158.

Van WykJA, Gerber HM, Alves RMR: Methods of infesting sheep with gastro-intestinal nematodes after cryopreservation: Dosing of larvae in gelatin capsules compared to dosing of larvae in water suspension. Onderstepoort J. Vet. Res., 1984, 51, 217-221.

\section{Sammendrag \\ Brugen af en agar-gel metode $i$ stor skala til høstning af Ascaris suum larver fra grises tarmindhold.}

Fire grupper med 3 grise i hver, blev podet med Ascaris suum æg. Grisene i grupperne 1 og 2 blev podet med 1000 æg, grisene i gruppe 2 og 4 med 10000 æg. På dag 10 og 21 post-infektion (p.i.), blev henholdsvis grupperne $1+2$ og $3+4$ slagtet, og tarmindholdet fra tyndtarmen blev opsamlet. Tyndtarmsindholdet blev blandet med agar til en slut koncentration på $1 \%$, hvorefter blandingen fik tid til at størkne. Larverne vandrede i løbet af en nat ud af gelen i $38^{\circ} \mathrm{C}$ $0.9 \%$ saltvand, og blev dagen efter opsamlet med en si (20 $\mu \mathrm{m}$ hulstørrelse) og talt. De larver, der var tilbage i agar-gelen, blev talt, efter at den smeltede gel var hældt igennem en si ( $20 \mu \mathrm{m}$ hulstørrelse). Resultaterne viste, at mere end $97 \%$ af larverne vandrede ud af gelen, og at larvesuspensionen var meget ren. Metoden gav desuden en høj ormehøst. De forskellige infektionsdoser påvirkede ikke signifikant larvehøsten, hvilket også var tilfældet med larvestadiet (dag 10 og 21 stadier). Variationen i tidsintervallet fra slagtning til inkubationsstart (interval fra 57-155 min) påvirkede ikke signifikant larvehøsten.

(Received February 7, 1997; accepted April 2, 1997).

Reprints may be obtained from: H-C. Slotved, Danish Centre for Experimental Parasitology, The Royal Veterinary and Agricultural University, Bülowsvej 13, DK-1870 Frederiksberg C, Denmark. E-mail: HCS@SVS.DK, Fax: (+45) 35282774, Telephone: (+45) 35300215. 